\title{
Modulating the luminescence of an iridium(III) complex incorporating a di(2-picolyl)anilino-appended bipyridine ligand with $\mathrm{Zn}^{2+}$ cations $\dagger$
}

\author{
Juan C. Araya, ${ }^{a}$ Juana Gajardo, ${ }^{a}$ Sergio A. Moya, ${ }^{a}$ Pedro Aguirre, ${ }^{b}$ Loïc Toupet, ${ }^{c}$ \\ J. A. Gareth Williams, ${ }^{d}$ Muriel Escadeillas, ${ }^{e}$ Hubert Le Bozec ${ }^{e}$ and \\ Véronique Guerchais*e
}

Received (in Montpellier, France) 28th September 2009, Accepted 13th November 2009

First published as an Advance Article on the web 1st December 2009

DOI: $10.1039 /$ b9nj00515c

\begin{abstract}
A novel iridium complex incorporating a di(2-picolyl)anilinoappended bipyridine ligand was synthesized and its optical properties studied. The presence of $\mathrm{Zn}^{2+}$ ions specifically perturbs the excited state, giving rise to a blue-shifted absorption and emission, and a shorter luminescence lifetime.
\end{abstract}

Cyclometallated iridium(III) complexes are well known for their rich photochemical and photophysical properties. ${ }^{1}$ These complexes, with low-lying triplet excited states and lifetimes of around a microsecond, behave as a promising class of phosphorescent dyes in optoelectronic devices ${ }^{2}$ and as new luminescent sensors for analytes, ${ }^{3}$ including protons, ${ }^{4}$ ions ${ }^{5}$ and biomolecules. ${ }^{6}$ Among them, cationic $N^{\wedge} N$-diimine complexes $\left[\operatorname{Ir}\left(N^{\wedge} C \text {-ppy)2( }\left(N^{\wedge} N\right)\right]^{+}\right.$(where Hppy is 2-phenylpyridine and $N^{\wedge} N$ represents a diimine, such as bpy or phen) are particularly attractive. ${ }^{7,8}$ They are readily synthesized, and the facile functionalization of diimine ligands provides access to diverse emissive states, allowing fine tuning of their optical properties.

We have previously shown that 2-phenylpyridines incorporating $\pi$-conjugated substituents are good building blocks for the construction of luminophores such as neutral, bis- ${ }^{9} a$ and tris-cyclometalated $^{9 b}$ 4-(4-(donor)styryl-2-phenylpyridine) iridium(III) and platinum(II) ${ }^{9 c}$ complexes, the interesting phosphorescent properties of which are governed by strong triplet intraligand transitions, promoted by an admixture of MLCT character $\left\{\mathrm{d} / \pi \rightarrow \pi^{*}\right\}$.

With our ongoing interest in the design of Ir(III) complexes, we have turned our attention to cationic bipyridine complexes incorporating a styryl group substituted with a di(2-picolyl)amino

${ }^{a}$ Universidad de Santiago de Chile, Facultad de Química y Biología, Avda. Libertador Bernardo O'Higgins 3363, Santiago de Chile, Chile

${ }^{b}$ Universidad de Chile, Facultad de Ciencias Quimica y

Farmacéuticas, Casilla 233, Santiago de Chile, Chile

${ }^{c}$ UMR 6626 (Institut de Physique de Rennes) CNRS-Université de

Rennes 1, Campus de Beaulieu, 35042 Rennes, France

${ }^{d}$ Department of Chemistry, University of Durham, Durham,

UK DH1 3LE

${ }^{e}$ UMR 6226 (Sciences Chimiques de Rennes) CNRS-Université de

Rennes 1, Campus de Beaulieu, 35042 Rennes, France.

E-mail: veronique.guerchais@univ-rennes1.fr;

Fax: + 33 (0)223236939

$\dagger$ Electronic supplementary information (ESI) available: Full experimental procedures, photophysical data and UV-vis titrations, details of the X-ray structure of $\mathbf{1}$. CCDC reference number 718415. For ESI and crystallographic data in CIF or other electronic format see DOI: $10.1039 / \mathrm{b} 9 \mathrm{nj} 00515 \mathrm{c}$.
(DPA) group (Scheme 1). The affinity of the nitrogen-based DPA group towards metal ions, such as $\mathrm{Ni}^{2+}, \mathrm{Zn}^{2+}$ and $\mathrm{Cd}^{2+}$ cations, has previously been demonstrated. ${ }^{10,11} \mathrm{We}$ anticipated that attachment of this receptor to an Ir-coordinated bipyridine ligand would allow modulation of the electronic structure upon coordination of metal cations at the DPA site by attenuating the electron donating ability of the amino group; the emission properties should be perturbed as a result.

We report herein the synthesis, characterization and photophysical properties of the $\operatorname{Ir}$ complex $\left[\operatorname{Ir}\left(N^{\wedge} C \text {-4-Me-ppy }\right)_{2}\right.$ $\left(N^{\wedge} N\right.$-bpy-CH $\left.\left.=\mathrm{CH}-\mathrm{C}_{6} \mathrm{H}_{4}-\mathrm{DPA}\right)\right]\left[\mathrm{PF}_{6}\right]$ (1) and the changes to its optical properties upon binding $\mathrm{Ni}^{2+}, \mathrm{Zn}^{2+}$ and $\mathrm{Cd}^{2+}$. The addition of $\mathrm{Zn}^{2+}$ gives a unique response, including a significant emission wavelength shift and a change in luminescence lifetime.

Target bipyridine L1 was readily prepared in $88 \%$ yield by means of a Horner-Wadsworth-Emmons condensation between a bisphosphonate-bipyridine derivative ${ }^{12}$ and the appropriate benzaldehyde amine, 2 (Scheme 1). The latter compound was obtained by following a reported procedure for the substitution of aniline by two equivalents of 2-chloromethylpyridine, followed by oxidation with $\mathrm{POCl}_{3}$ in $\mathrm{DMF}$ to introduce the aldehyde functionality. ${ }^{10 e}$ The ${ }^{1} \mathrm{H}$ and ${ }^{13} \mathrm{C}$ NMR spectra of $\mathbf{L 1}$ were in agreement with the proposed structure. Complex 1 was subsequently prepared by the reaction of $\mathbf{L 1}$ with $\mathrm{Ir}$ dimer $\left[\operatorname{Ir}\left(N^{\wedge} \mathrm{C} \text {-4-Me-ppy }\right)_{2}(\mu-\mathrm{Cl})\right]_{2}$ in $\mathrm{CH}_{2} \mathrm{Cl}_{2}$ in the presence of $\mathrm{AgPF}_{6}$ (Scheme 1). It was isolated as orange-red

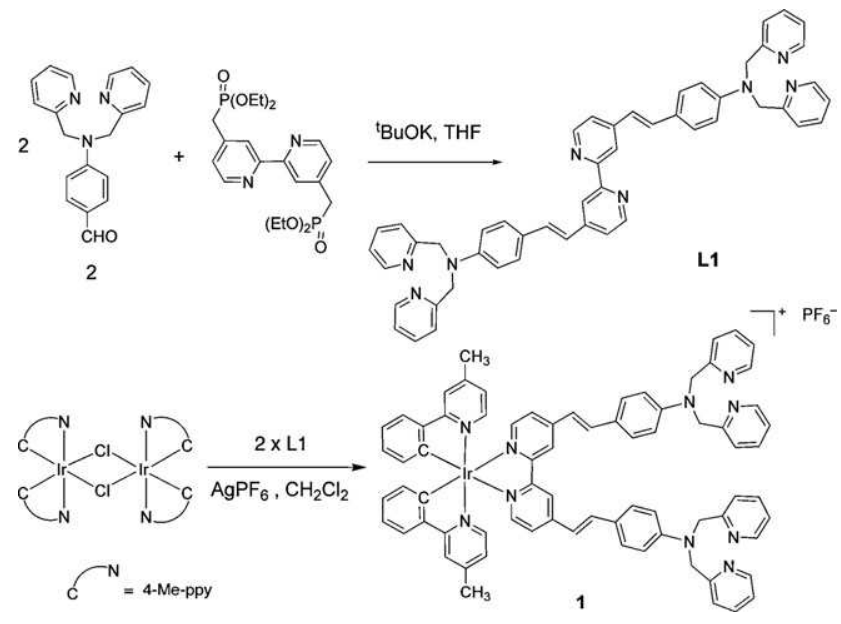

Scheme 1 Preparation of $\mathbf{L} 1$ and $\mathbf{1}$. 


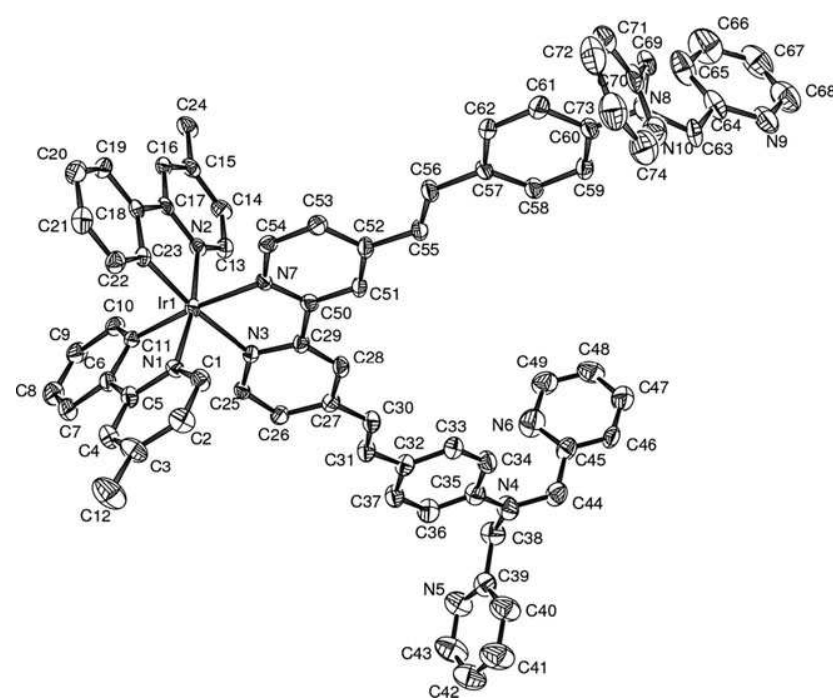

Fig. 1 An ORTEP plot of 1 with thermal ellipsoids at the $50 \%$ probability level; $T=120 \mathrm{~K}$. Hydrogen atoms are omitted for clarity.

microcrystals in $70 \%$ yield after recrystallization from $\mathrm{CH}_{2} \mathrm{Cl}_{2}$-pentane; the structure determined by $\mathrm{X}$-ray diffraction is shown in Fig. 1. The initial $E$ configuration of the two $\mathrm{C}=\mathrm{C}$ double bonds was retained upon metal complexation. However, upon UV irradiation, the $\mathrm{C}=\mathrm{C}$ bonds of $\mathbf{1}$ underwent a slow $E-Z$ isomerization process, as revealed by ${ }^{1} \mathrm{H}$ NMR spectroscopy.

The electronic absorption and luminescence data for $\mathbf{1}$ and $\mathbf{L 1}$ are summarized in Table $\mathrm{S} 1 . \dagger$ The absorption spectrum of 1 displays high energy bands in the UV region $(250-340 \mathrm{~nm})$ assigned to intraligand IL ( $\pi \rightarrow \pi^{*}$ ) (bpy and ppy) transitions (Fig. 2). An intense low energy absorption band centered at $449 \mathrm{~nm}\left(\varepsilon=27500 \mathrm{dm}^{3} \mathrm{~mol}^{-1} \mathrm{~cm}^{-1}\right)$ probably arises from the influence of the electron donating nature of the amino group. The effect of the amino substituent is also seen in the behavior of the corresponding uncoordinated ligand $\mathbf{L 1}$, which displays a low energy absorption band $\left(\lambda_{\max }=385 \mathrm{~nm}\right)$. The $64 \mathrm{~nm}$ red shift in the IL band of $\mathbf{L 1}$ upon complexation to iridium(III) (highlighted in Figure $\mathrm{S} 1 \dagger$ ) can be attributed to the enhanced $\pi$-acceptor character of the bpy moiety upon coordination, lowering the LUMO energy level. ${ }^{13}$ Based on the spectra of complexes such as $\left[\operatorname{Ir}\left(N^{\wedge} C \text {-ppy }\right)_{2}\left(N^{\wedge} N \text {-bpy }\right)\right]^{+},{ }^{7,8}$ one or more bands due to MLCT transitions $\left[\mathrm{d} \pi(\mathrm{Ir}) \rightarrow \pi^{*}\right.$ (diimine and ppy)] would be anticipated over the range $330-400 \mathrm{~nm}$; in the present complex, they are superimposed by the tail of the low energy band associated with the aminostyryl unit.

Uncoordinated ligand $\mathbf{L 1}$ is fluorescent in solution at room temperature $(\mathrm{RT})\left(\lambda_{\max }=486 \mathrm{~nm}\right.$ in $\left.\mathrm{CH}_{2} \mathrm{Cl}_{2}\right)$. In contrast, complex $\mathbf{1}$ is non-emissive in solution at RT. Simpler iridium(III) complexes, such as $\left[\operatorname{Ir}\left(N^{\wedge} C \text {-ppy }\right)_{2}\left(N^{\wedge} N \text {-bpy }\right)\right]^{+}$, display luminescence from the lowest-lying triplet state under these conditions, promoted by spin-orbit coupling. The absence of RT phosphorescence in the present case suggests the introduction of a non-radiative decay pathway that is not open to simpler derivatives and/or a radiative rate constant, $k_{\mathrm{r}}$, that is unusually low; this is confirmed by its behavior at $77 \mathrm{~K}$. Under these conditions, the complex emits brightly, displaying a highly structured spectrum deep into the red
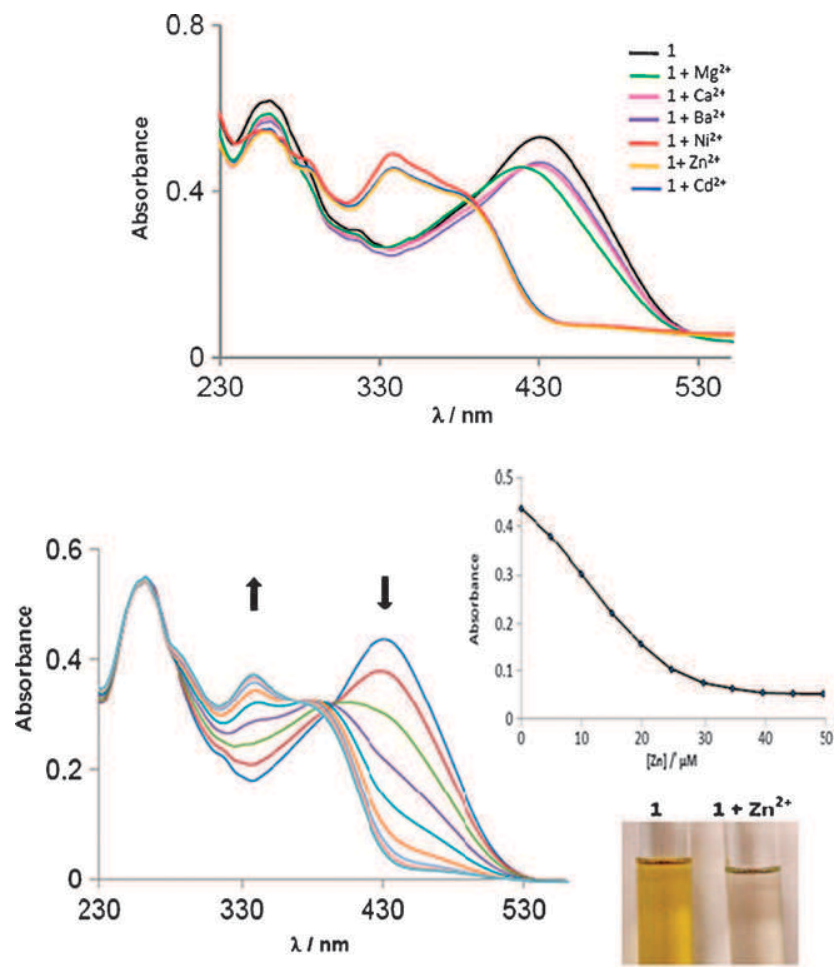

Fig. 2 Top: UV-vis absorption spectral changes of 1 (conc. $=1 \times$ $10^{-5} \mathrm{M}$ in $\mathrm{CH}_{3} \mathrm{CN}$ ) after the addition of 50 equivalents of $\mathrm{Ba}^{2+}$, $\mathrm{Ca}^{2+}, \mathrm{Mg}^{2+}, \mathrm{Cd}^{2+}, \mathrm{Zn}^{2+}$ and $\mathrm{Ni}^{2+}$ ions. Bottom: UV-vis absorption spectral changes of 1 upon addition of incremental ( 0.5 equivalent) amounts of $\mathrm{Zn}\left(\mathrm{ClO}_{4}\right)_{2}$. The inset shows a plot of absorbance against $\left[\mathrm{Zn}^{2+}\right]$ monitored at $430 \mathrm{~nm}$.

region $\left(\lambda_{\max }{ }^{0-0}=640 \mathrm{~nm}, \Delta \nu=1400 \mathrm{~cm}^{-1}\right)$ (Fig. 3). The lifetime of $67 \mu \mathrm{s}$ is exceptionally long, confirming that $k_{\mathrm{r}}$ is indeed low. The values are in stark contrast to those of, for example, $\left[\operatorname{Ir}\left(N^{\wedge} C \text {-ppy }\right)_{2}\left(N^{\wedge} N-4,4^{\prime}-\mathrm{Me}_{2} \text {-bpy }\right)\right]^{+}\left(\lambda_{\mathrm{em}}=506 \mathrm{~nm}\right.$ at $77 \mathrm{~K}, \tau=4.83 \mu \mathrm{s}),{ }^{7 d}$ where the emission is attributed to an MLCT state. Evidently, in complex 1, the emission emanates from a state of ${ }^{3}$ IL character localized on the styryl-substituted bpy ligand, with relatively low metal participation; triplet excited states, in which the metal plays only a minor role, are expected to have longer radiative lifetimes owing to less efficient spin-orbit coupling pathways. The triplet radiative rate constant is probably so low that, at RT, the excited state is essentially fully deactivated by the faster $E-Z$ isomerization process, accounting for the lack of emission. In free ligand L1, in contrast, the fluorescence is fast enough to be competitive with this process.

The behavior of $\mathbf{1}$ in the presence of various metal cations was studied $\left(\mathrm{Ba}^{2+}, \mathrm{Ca}^{2+}, \mathrm{Mg}^{2+}, \mathrm{Ni}^{2+}, \mathrm{Zn}^{2+}\right.$ and $\mathrm{Cd}^{2+}$ as their perchlorate salts in $\mathrm{CH}_{3} \mathrm{CN}$ ). The absorption spectrum was dramatically modified upon adding $\mathrm{Ni}^{2+}, \mathrm{Zn}^{2+}$ and $\mathrm{Cd}^{2+}$ (Fig. 2). The solution color visibly changed from orange to colorless, the low energy absorption band $\left(\lambda_{\max } 430 \mathrm{~nm}\right.$ in $\mathrm{CH}_{3} \mathrm{CN}$ ) decreased and a new band at $\sim 330 \mathrm{~nm}$ concomitantly evolved (Fig. 2 and Fig. S3†). In contrast, no significant changes were observed with $\mathrm{Ba}^{2+}, \mathrm{Ca}^{2+}$ and $\mathrm{Mg}^{2+}$.

The blue shift of the absorption band with $\mathrm{Ni}^{2+}, \mathrm{Zn}^{2+}$ and $\mathrm{Cd}^{2+}$ is intuitively consistent with the binding of the metal ion 


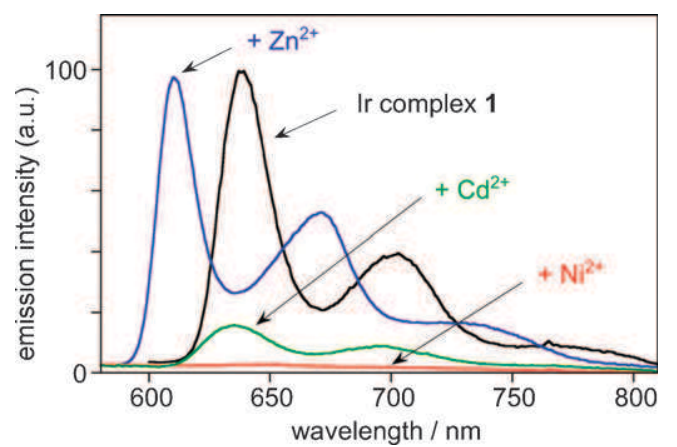

Fig. 3 Luminescence spectral changes $(77 \mathrm{~K})$ of 1 (conc. $=3 \times 10^{-6} \mathrm{M}$ ) in ethanol-methanol $(4: 1, \mathrm{v} / \mathrm{v})$ upon the addition of $\mathrm{M}\left(\mathrm{ClO}_{4}\right)_{2}(\mathrm{M}=\mathrm{Ni}$, $\mathrm{Zn}, \mathrm{Cd})\left(\right.$ conc. $\left.=6 \times 10^{-5} \mathrm{M}\right) ; \lambda_{\mathrm{ex}}=385 \mathrm{~nm}$ (isosbestic point).

at the DPA amine nitrogen, which would reduce its donating ability, lowering the energy of the highest-occupied molecular orbital. The stoichiometric ratio of the species formed between complex 1 and $\mathrm{M}^{2+}$ was estimated to be $1: 2$ in accordance with the presence of two DPA receptors. An isosbestic point at $385 \mathrm{~nm}$ is consistent with a two-species equilibrium $\left(1+2 \mathrm{M}^{2+} \rightarrow \mathbf{1} \cdot\left(\mathrm{M}^{2+}\right)_{2}\right)$. The following binding constants, $\log K_{\mathrm{s}}$, were determined: $\mathrm{Ni}^{2+}=7.01 \pm 0.03, \mathrm{Cd}^{2+}=6.56 \pm$ 0.61 and $\mathrm{Zn}^{2+}=5.46 \pm 0.12$.

The effect of the same set of metal ions on the luminescence of 1 at $77 \mathrm{~K}$ was also investigated. The emission $\left(\lambda_{\max }=640 \mathrm{~nm}\right)$ was completely quenched upon adding $\mathrm{Ni}^{2+}$ ions, whereas $\mathrm{Cd}^{2+}$ lead only to partial quenching and a scarcely perceptible blue shift (3 nm) (Fig. 3). Most strikingly, the coordination of $\mathrm{Zn}^{2+}$ ions induced a unique response: a blue-shifted emission $\left(\lambda_{\max }{ }^{0-0}=610 \mathrm{~nm}\right)$ of the intensity comparable to $\mathbf{1}$ (for excitation at the isosbestic point at $385 \mathrm{~nm}$ ) with a lifetime of $34 \mu$ s was observed, indicative of the formation of a new emissive species. In the presence of a sub-stoichiometric quantity of $\mathrm{Zn}^{2+}$, the emission profiles of the two species - the ion-free complex 1 and the $\mathrm{Zn}^{2+}$-coordinated complex-were independently observable at $77 \mathrm{~K}$ (Fig. S5 $\dagger$ ). Two distinct sets of vibrational bands were clear, and the distinctly different decay curves registered at 610 and $637 \mathrm{~nm}$, respectively, are in line with those of the fully bound and unbound species. Interestingly, the addition of $\mathrm{H}^{+}$ions (from trifluoroacetic acid) lead to related but much smaller effects on the emission: a blue shift of $12 \mathrm{~nm}$ and a small decrease in the lifetime to $50 \mu \mathrm{s}$.

As for the absorption, the emission blue shift can be interpreted in terms of a stabilisation of the highest occupied molecular orbitals as the $\mathrm{N}$ lone pair becomes bound to the $\mathrm{Zn}^{2+}$ ion. That selectivity for $\mathrm{Cd}^{2+}$ is observed only in emission and not in absorption presumably reflects a subtle difference in the electronic distribution in the triplet and singlet excited states. The selective blue shift induced by $\mathrm{Zn}^{2+}$ implies that, in the excited state, the more charge-dense $\mathrm{Zn}^{2+}$ ion interacts more strongly with the amino group of the DPA unit than does $\mathrm{Cd}^{2+}$. The softer nature of the $\mathrm{Cd}^{2+}$ ion probably means that its predominant mode of binding to the DPA in the excited state is via the picolyl units.

In summary, complex 1 displays an unusual phenomenon of selective zinc-dependent wavelength-and lifetime-modulation of its emission.
This work was supported by ECOS-CONICYT (Action CO7E02), COST D35 and Region Bretagne (SIE 211-B3-11). This research was performed as part of the Chilean-French "Joint Laboratory for Inorganic Functional Materials "(LIAMIF_836_). We thank J.-L. Fillaut and P.-H. Lanoë for assistance. J. C. A., J. G., P. A. and S. A. M. thank Fondecyt 1085135.

\section{Experimental}

\section{Preparation of 1}

Chloride-bridged dimer $\left[\operatorname{Ir}\left(N^{\wedge} C \text {-4-Me-ppy }\right)_{2}(\mu-\mathrm{Cl})\right]_{2}(100 \mathrm{mg}$, $0.09 \mathrm{mmol})$, bipyridine derivative $\mathbf{L 1}(140 \mathrm{mg}, 0.19 \mathrm{mmol})$ and $\mathrm{AgPF}_{6}(60 \mathrm{mg}, 0.24 \mathrm{mmol})$ were mixed in $\mathrm{CH}_{2} \mathrm{Cl}_{2}(10 \mathrm{~mL})$. The reaction mixture was stirred under $\mathrm{Ar}$ for $2 \mathrm{~h}$. The solution was then concentrated to dryness and the product extracted with $\mathrm{CH}_{2} \mathrm{Cl}_{2}(3 \times 5 \mathrm{~mL})$. Crystallization from a $\mathrm{CH}_{2} \mathrm{Cl}_{2}$-diethyl ether mixture gave an orange-red powder (186 mg, 70\%). ${ }^{1} \mathrm{H}$ NMR (500 MHz, $\mathrm{CDCl}_{3}$ ): 8.68 (s, 2H, $\mathrm{H}_{3}$-bpy), 8.61 (d, 4H, $\mathrm{H}_{6}$-Py*, $\left.{ }^{3} \mathrm{~J}=4.4 \mathrm{~Hz}\right), 7.70(\mathrm{~s}, 2 \mathrm{H}$, $\mathrm{H}_{6}$-bpy), 7.65 (m, 2H, $\mathrm{H}_{3}-\mathrm{Ph}, 4 \mathrm{H}, \mathrm{H}_{3}-\mathrm{Py} *$ and $2 \mathrm{H}, \mathrm{H}_{3}-\mathrm{Py}$ ), $7.48\left(\mathrm{~d}, 4 \mathrm{H}, \mathrm{C}_{6} \mathrm{H}_{4},{ }^{3} \mathrm{~J}=8.9 \mathrm{~Hz}\right), 7.44\left(\mathrm{~d}, 2 \mathrm{H}, \mathrm{H}_{6}-\mathrm{Py}\right.$, $\left.{ }^{3} J=6.0 \mathrm{~Hz}\right), 7.41\left(\mathrm{~d}, 2 \mathrm{H},=\mathrm{CH}_{8},{ }^{3} J=16.2 \mathrm{~Hz}\right), 7.27$ (m, 2H, $\mathrm{H}_{5}$-bpy), 7.25 (d, 4H, $\mathrm{H}_{4}-\mathrm{Py} *{ }^{3} J=7.9 \mathrm{~Hz}$ ), 7.20 $\left(\mathrm{dd}, 4 \mathrm{H}, \mathrm{H}_{5}-\mathrm{Py} *,{ }^{3} \mathrm{~J}=6.8 \mathrm{~Hz},{ }^{3} \mathrm{~J}=5.03 \mathrm{~Hz}\right), 7.11(\mathrm{~d}, 2 \mathrm{H}$, $\left.=\mathrm{CH}_{7},{ }^{3} \mathrm{~J}=16.2 \mathrm{~Hz}\right), 7.01\left(\mathrm{td}, 2 \mathrm{H}, \mathrm{H}_{4}-\mathrm{Ph},{ }^{3} \mathrm{~J}=7.5 \mathrm{~Hz}\right.$, $\left.{ }^{4} J=1.0 \mathrm{~Hz}\right), 6.90\left(\mathrm{td}, 2 \mathrm{H}, \mathrm{H}_{5}-\mathrm{Ph},{ }^{3} J=7.5 \mathrm{~Hz},{ }^{4} J=1.2 \mathrm{~Hz}\right)$, $6.84\left(\mathrm{dd}, 2 \mathrm{H}, \mathrm{H}_{5}-\mathrm{Py},{ }^{3} J=6.0 \mathrm{~Hz},{ }^{4} \mathrm{~J}=1.4 \mathrm{~Hz}\right), 6.69(\mathrm{~d}, 4 \mathrm{H}$, $\left.\mathrm{C}_{6} \mathrm{H}_{4},{ }^{3} J=8.8 \mathrm{~Hz}\right), 6.34\left(\mathrm{dd}, 2 \mathrm{H}, \mathrm{H}_{6}-\mathrm{Ph},{ }^{3} \mathrm{~J}=7.5 \mathrm{~Hz},{ }^{4} \mathrm{~J}=\right.$ $0.8 \mathrm{~Hz}), 4.86\left(\mathrm{~s}, 8 \mathrm{H}, \mathrm{CH}_{2}\right)$ and $2.49\left(\mathrm{~s}, 6 \mathrm{H}, \mathrm{CH}_{3}\right) .{ }^{13} \mathrm{C}\left[{ }^{1} \mathrm{H}\right]$ NMR (75 MHz, $\left.\mathrm{CDCl}_{3}\right)$ : $167.23\left(\mathrm{C}_{2}\right.$-py), 158.13 ( $\mathrm{C}_{2}$-py*), 156.05 ( $\mathrm{C}_{2}$-bpy), $151.67\left(\mathrm{C}_{1}-\mathrm{Ph}\right), 149.74\left(\mathrm{C}_{6}\right.$-py* $), 149.53$ $\left(\mathrm{C}_{4}\right.$-py $), 149.38 \quad\left(\mathrm{C}_{9}\right), 149.13 \quad\left(\mathrm{C}_{4}\right.$-bpy $), 149.05 \quad\left(\mathrm{C}_{6}\right.$-bpy $)$, 147.90 ( $\mathrm{C}_{6}$-py), $143.64\left(\mathrm{C}_{2}-\mathrm{Ph}\right), 137.19\left(\mathrm{C}_{8}\right), 136.89\left(\mathrm{C}_{4}-\mathrm{py}^{*}\right)$, $131.84\left(\mathrm{C}_{6}-\mathrm{Ph}\right), 130.32\left(\mathrm{C}_{5}-\mathrm{Ph}\right), 129.65\left(\mathrm{C}_{10}\right), 124.90\left(\mathrm{C}_{12}\right)$, $124.36\left(\mathrm{C}_{3}-\mathrm{Ph}\right), 124.26$ ( $\mathrm{C}_{5}$-py), $122.44 \quad\left(\mathrm{C}_{5}\right.$-bpy $), 122.17$ $\left(\mathrm{C}_{5}\right.$-py* and $\mathrm{C}_{3}$-bpy), $122.08\left(\mathrm{C}_{4}-\mathrm{Ph}\right), 120.80\left(\mathrm{C}_{3}\right.$-py*), $120.06\left(\mathrm{C}_{3}\right.$-py), $119.70\left(\mathrm{C}_{7}\right), 112.54\left(\mathrm{C}_{11}\right), 56.98\left(\mathrm{CH}_{2}\right)$ and $21.29\left(\mathrm{CH}_{3}\right)$. Elemental analysis: $\mathrm{C}_{74} \mathrm{H}_{62} \mathrm{~F}_{6} \mathrm{~N}_{10} \mathrm{IrP} \cdot 0.5 \mathrm{CH}_{2} \mathrm{Cl}_{2}$ calc. C, 60.83, H, 4.32, N, 9.52. Found: C, 60.20, H, 4.36, N, 9.18\%. HRMS: $m / z$ calc. for $\mathrm{C}_{74} \mathrm{H}_{62} \mathrm{~N}_{10} \mathrm{Ir}$ : 1283.47883 , found: 1283.4793 .

\section{References}

1 (a) I. M. Dixon, J.-P. Collin, J.-P. Sauvage, L. Flamigni, L. S. Encinas and F. Barigelletti, Chem. Soc. Rev., 2000, 29, 385; (b) M. S. Lowry and S. Bernhard, Chem.-Eur. J., 2006, 12, 7970; (c) L. Flamigni, A. Barbieri, C. Sabatini, B. Ventura and F. Barigelletti, Top. Curr. Chem., 2007, 281, 143; (d) P.-T. Chou and Y. Chi, Chem.-Eur. J., 2007, 13, 380; (e) J. A. G. Williams, A. J. Wilkinson and V. L Whittle, Dalton Trans., 2008, 2081.

2 M. A. Baldo, M. E. Thompson and S. R. Forrest, Nature, 2000, 403, 750; Highly Efficient OLEDs with Phosphorescent Materials, ed. H. Yersin, Wiley-VCH, Berlin, 2007.

3 (a) Z. Liu, Z. Bian, J. Bian, Z. Li, D. Nie and Huang, Inorg. Chem., 2008, 47, 8025; (b) H. Chen, Q. Zhao, Y. Wu, F. Li, H. Yang, T. Yi and C. Huang, Inorg. Chem., 2007, 46, 11075.

4 (a) M. Licini and J. A. G. Williams, Chem. Commun., 1999, 1943; (b) W. Goodall and J. A. G. Williams, J. Chem. Soc., Dalton Trans., 2000, 2893; (c) K. Konishi, H. Yamaguchi and A. Harada, Chem. Lett., 2006, 35, 720. 
5 (a) M.-L. Ho, F.-M. Hwang, P.-N. Chen, Y.-H. Hu, Y.-M. Cheng, K.-S. Chen, G.-H. Lee, Y. Chi and P.-T. Chou, Org. Biomol. Chem., 2006, 4, 98; (b) Q. Zhao, S. Liu, M. Shi, F. Li, H. Jing, T. Yi and C. Huang, Organometallics, 2007, 26, 5922; (c) Q. Zhao, T. Cao, F. Li, X. Li, H. Jing, T. Yi and C. Huang, Organometallics, 2007, 26, 2077; (d) M. Schmittel and H. Lin, Inorg. Chem., 2007, 46, 9139; (e) K. K.-W. Lo, J. S.-Y. Lau, D. K.-K. Lo and L. T.-L. Lo, Eur. J. Inorg. Chem., 2006, 4054.

6 K. K.-W. Lo, D. C.-M. Ng and D. C.-M. Chung, Organometallics, 2001, 20, 4999; K. K.-W. Lo, K. H. K. Tsang, K. S. Sze, C. K. Chung, T. K. M. Lee, K. Y. Zhang, W. K. Hui, C. K. Li, J. S.-Y. Lau, D. C. M. Ng and N. Y. Zhu, Coord. Chem. Rev., 2007, 251, 2292; K. K.-W. Lo, K. Y. Zhang, S.-K. Leung and M.-C. Tang, Angew. Chem., Int. Ed., 2008, 47, 2213.

7 See, inter alia: (a) F. O. Garces, K. A. King and R. J. Watts, Inorg. Chem., 1988, 27, 3464; (b) F. Neve, A. Crispini, S. Campagna and S. Serroni, Inorg. Chem., 1999, 38, 2250; (c) E. A. Plummer, J. W. Hofstraat and L. De Cola, Dalton Trans., 2003, 2080; (d) M. Lepeltier, T. K.-M. Lee, K. K.-W. Lo, L. Toupet, H. Le Bozec and V. Guerchais, Eur. J. Inorg. Chem., 2005, 110; (e) M. Polson, S. Fracasso, V. Bertolasi, M. Ravaglia and F. Scandola, Inorg. Chem., 2004, 43, 1950; (f) F. De Angelis, S. Fantacci, N. Evans, C. Klein, S. M. Zakeeruddin, J.-E. Moser, K. Kalyanasundaram, H. J. Bolink, M. Gratzel and M. K. Nazeeruddin, Inorg. Chem., 2007, 46, 5989.

8 Q. Zhao, S. Liu, M. Shi, C. Wang, M. Yu, L. Li, F. Li, T. Yi and C. Huang, Inorg. Chem., 2006, 45, 6152; C. Dragonetti, L. Falciola, P. Mussini, S. Righetto, D. Roberto, R. Ugo,
A. Valore, F. De Angelis, S. Fantacci, A. Sgamellotti, M. Ramon and M. Muccini, Inorg. Chem., 2007, 46, 8533.

9 (a) M. Lepeltier, H. Le Bozec, V. Guerchais, T. K.-M. Lee and K. K.-W. Lo, Organometallics, 2005, 24, 6069; (b) M. Lepeltier, T. K.-M. Lee, K. K.-W. Lo, L. Toupet, H. Le Bozec and V. Guerchais, Eur. J. Inorg. Chem., 2007, 2734; (c) B. Yin, F. Niemeyer, J. A. G. Williams, J. Jiang, A. Boucekkine, L. Toupet, H. Le Bozec and V. Guerchais, Inorg. Chem., 2006, 45, 8584.

10 (a) X. Peng, J. Du, J. Fan, J. Wang, Y. Wu, J. Zhao, S. Sun and T. Xu, J. Am. Chem. Soc., 2007, 129, 1500; (b) L. Zhang, R. J. Clark and L. Zhu, Chem.-Eur. J., 2008, 14, 2894; (c) T. Sakamoto, A. Ojida and I. Hamachi, Chem. Commun., 2009, 141; (d) A. Takebayashi, S. Shinkai, M. Ikeda and M. Takeuchi, Org. Biomol. Chem., 2008, 6, 493; (e) X. Huang, Z. Guo, W. Zhu, Y. Xie and H. Tian, Chem. Commun., 2008, 5143.

11 Two examples of metal complexes incorporating the DPA unit have been very recently published: M.-W. Louie, H.-W. Liu, M. H.-C. Lam, T.-C. Lau and K. K.-K. Lo, Organometallics, 2009, 28, 4297; N. Zhao, Y.-H. Wu, H.-M. Wen, X. Zhang and Z.-N. Chen, Organometallics, 2009, 28, 5603.

12 O. Maury, J.-P. Guégan, T. Renouard, A. Hilton, P. Dupeau, N. Sandon, L. Toupet and H. Le Bozec, New J. Chem., 2001, 25, 1553.

13 (a) W. Goodall and J. A. G. Williams, Chem. Commun., 2001, 2514; (b) W. Leslie, A. S. Batsanov, J. A. K. Howard and J. A. G. Williams, Dalton Trans., 2004, 623; (c) W. Leslie, R. A. Poole, P. R. Murray, L. J. Yellowlees, A. Beeby and J. A. G. Williams, Polyhedron, 2004, 23, 2769; (d) D. Roberto, F. Tessore, R. Ugo, S. Bruni, A. Manfredi and S. Quici, Chem. Commun., 2002, 846. 